\title{
LESSON LEARNT FROM KREDIT TRIGUNA: THE HOUSING FINANCE FOR LOW-INCOME COMMUNITY
}

\author{
Dyah Widi Astuti \\ PIPW LPPM Universitas Sebelas Maret \\ JI. Ir. Sutami No. 36A, Jebres, Surakarta Telp: (0271)632368 Fax: (0271)632916 \\ Email : dyahwidi@yahoo.com
}

\begin{abstract}
ABSTRAK
Financial aid or loan designed specifically for housing the low income community, especially they are working in informal sector, is necessary. To answer the need, about two decades ago, Bank Tabungan Negara (BTN) or The State Savings Bank had introduced a loan package, named Kredit Triguna. Designed as a mixed microcredit policy, this loan implemented a fully concept of integrated approach. But it was only available for two years, and then discontinued. As one of the best practice microfinance programs at the time, this condition was considered as a unique case. This paper aims to evaluate the previous microcredit policy, that was Kredit Triguna, in its implementation and to identify reasons for its success or failure in performance. As a sample of case study, a project of housing redevelopment in Kalianyar riverbank, Mojosongo, Surakarta using the loan is observed. The result of the study will help in developing new alternative scheme in housing finance for the low-income community.
\end{abstract}

Kata Kunci: housing finance, low-income, informal sector

\section{PROBLEMS OF URBAN HOUSING FOR LOW-INCOME COMMUNITY}

High population growth in cities in developing countries all over the world without the availability of employment field causes the numbers of people belong to low-income group increases, which has negative impacts in terms of urban development.

In the context of urban housing, the growth of slum and squatter areas, characterized physically by below-standard housing, bad infrastructures availability, bad sanitation, flooded area and environmental pollution, is one of the impacts. It is related to the statement of Srisoewarni (2002 in Kimpraswil website), that dealing with urban housing means to deal with the growth of slum district and neighborhoods in inner-city, which is caused by urban poverty.

Panudju (1999), as well as Sheng (2000), described that housing provision for low-income community is a complex problem and has some constraints, such as financial constraint, limitation of land availability and land price, limitation of housing and environment facilities and infrastructures, and the last, building material and building codes/regulations.
Furthermore, economic condition is believed to be one potential reason. Almost all households need a loan to gain home ownerships, but many low-income households do not have access to institutional housing finance, because their income-earners work in informal sector without a fixed income. The lack of key assets that could be used as collateral in conventional system is another reason. As a result, they cannot get loan from financial institution as a mean to improve their housing conditions (Sheng, in CDSI, 2000:6466). In addition, so far no financial institution can provide any loan for housing financing for the poor without any involvement of the government.

\section{KREDIT TRIGUNA, THE EMPHASIS OF ENABLING STRATEGY AND INTEGRATED APPROACH}

In order to improve housing and living condition, Bank Tabungan Negara (BTN) or the State Savings Bank had, introduced a loan package in 1994 and effectively was started in September 1996, named Kredit Triguna. This loan supported Pembangunan Perumahan Bertumpu Pada Kelompok (P2BPK) - the community-based housing program; it was 
granted to a community based organization, known as Kelompok Swadaya Masyarakat (KSM) or self-help group, not to individual households. That was designed to ensure access to institutional finance for low-income communities (BTN, 1999).

The program consisted of three steps, as the word Triguna implies, in which each step can be used by community to finance a type of activities. ${ }^{1}$ In the first step, the first loan was for land acquisition, including land purchasing, parcelling and legalization process. The second step was to finance housing construction, including social and public facilities needed, and the last step, about $10 \%-15 \%$ of the total loan, was for productive activities to improve income of group's member.

The Indonesian government played the role as an enabler to help low-income community in housing provision. It designed Kredit Triguna under soft conditions, with the loan duration of 20 years and interest rate $8.5 \%$ pa, compared to market interest rates of about $15-19 \%$ pa, meant that amount of 6.5 $10.5 \%$ of interest rate per annum was subsidized by the government.
The loan provided the resources but relied on the community for housing construction. The advantage of the program was that most of the housing development cost was built by the community itself, so it was not necessary for the government to bear a big amount of money to provide housing for low-income group (Panudju, 1999).

In the context of housing arrangement problems, as a mixed microcredit policy, this loan applied integrated approaches from physical, economy and socio-cultural sides. To simplify, helping the poor to access key assets (credit and land) and increasing the productivity gave the poor chances to improve physical condition of housing and its environment, to have better quality of life, and at the same time, to break their poverty condition.

\footnotetext{
1 No specific amount or percentage for each step, except for productive loan that was usually about $10 \%-15 \%$ from total amount. In addition, BTN as the supplier used plafond system for land price, which was extremely low comparing to normal price. In 1996 the maximum land price allowed to buy was Rp 5,000.00/m2 only.
}

Diagram 1. Activities Covered by Kredit Triguna

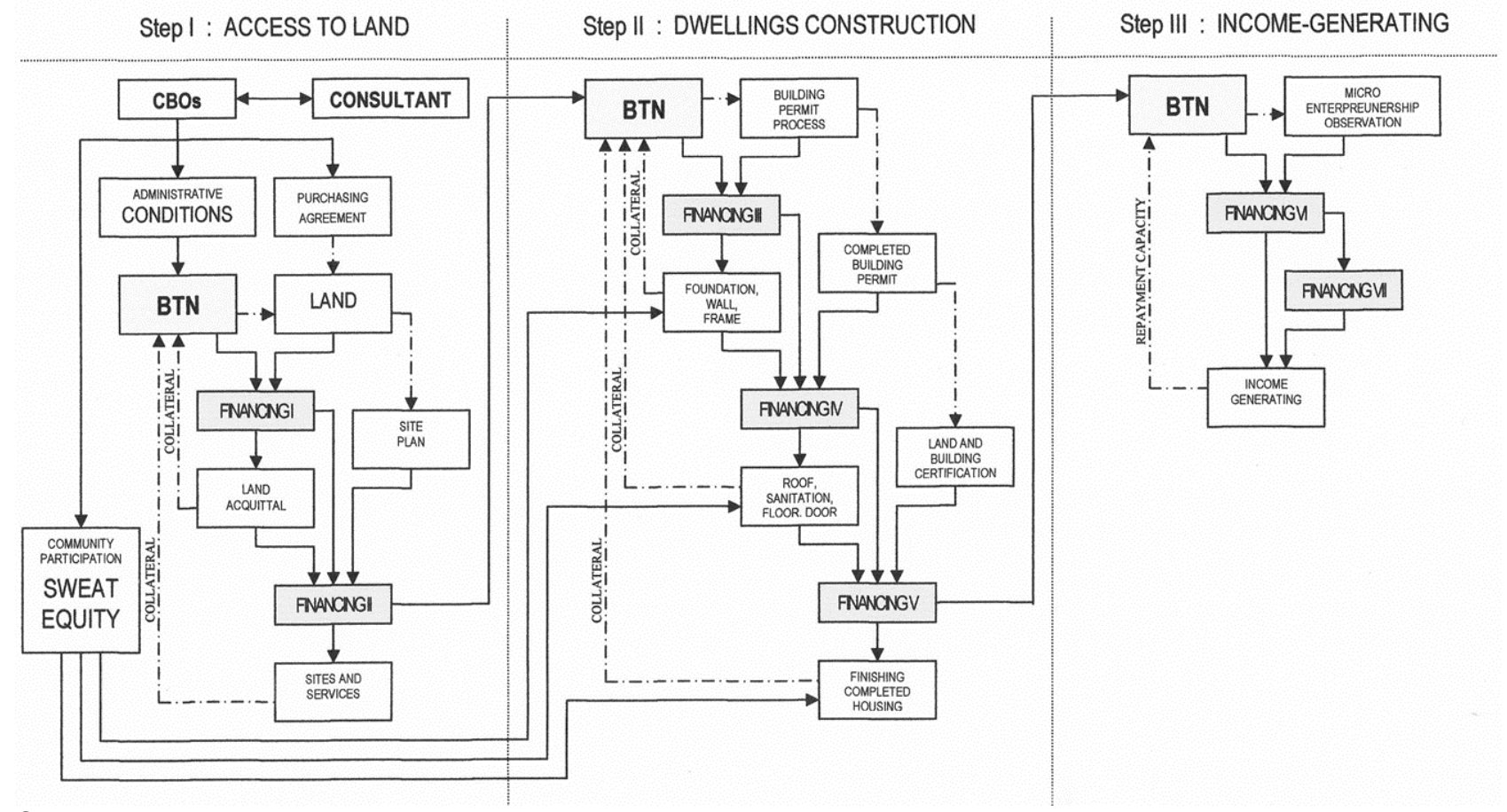

Source : Research Work, in Astuti, 2003 
THE DISCONTINUITY OF KREDIT TRIGUNA

As a specific loan designed for the poor, it needs more explanation then, for what reasons, that Kredit Triguna was available only for two years, between 1996-1998. After that period of time, it was discontinued. ${ }^{2}$ One reason was that housing constructed by this loan scheme should meet the minimum standard of housing based on BTN standard, and most of the low-cost housing built cannot meet this standard. In addition, bureaucracy system within BTN was big constraint for community in self-help groups. In that condition, it was very difficult for Triple Functions Loan to reach most of low-income community because the requirements were too complicated (Astuti, 2003).

Also, based on the data from BTN as the supplier of Triple Functions Loan in the performance developments record of the last 3 years, it is found that repayment record of this scheme was not satisfactory. The first proposition occurs that the loan for income generating activities did not work to improve their economic condition. Or the second proposition, as a loan given to a community as a group, not to an individual household, the responsibility for a repayment was reduced (Astuti, 2003).

Table 1. National Performance Record of Kredit Triguna 2001 - 2003

\begin{tabular}{|l|l|l|l|l|}
\hline MONTH & DEBT & $\begin{array}{c}\text { BALANCE } \\
\text { (Rp.) }\end{array}$ & \multicolumn{2}{|c|}{ COLLECTIBILITY } \\
\hline Dec '01 & 311 & $4,152,000,000$ & 78.20 & Fair \\
\hline Dec '02 & 287 & $3,968,000,000$ & 25.98 & Bad \\
\hline Jun '03 & 279 & $3,766,000,000$ & -1.05 & Worst \\
\hline
\end{tabular}

Source: BTN

Moreover, because of the impact of economic crisis in Indonesia, many banks were technically bankrupt. BTN as a state bank was able to survive, but then cut off from their large funding source for subsidized financing. Based on letter from Ministry of State Owned, August 21, 2002, BTN changed its function to be commercial banking, and consequently, it more focuses on nonsubsidized housing financing

\footnotetext{
2 No specific informations got to explain, only that the scheme is not available anymore. Observing the reasons of the discontinuity is one part of the study.
}

\section{CASE STUDY: THE IMPLEMENTATION OF KREDIT TRIGUNA IN HOUSING REDEVELOPMENT PROJECT}

\section{Background of Project}

One of the first projects for housing the poor using Kredit Triguna had been applied in Housing and Urban Renewal Development Action Plan and Final Engineering Design for Mojosongo, Surakarta, specifically located on Kalianyar riverbank. It was a squatter area that was full with illegal and nonpermanent/semi-permanent housings, which population density more than 500 persons per hectareat the time. Most of the occupants were outsiders with low-income and also low education, working in informal sector. They started to build new environment in the riverbank, a part of government land, since around 1985 and had been growing fast.

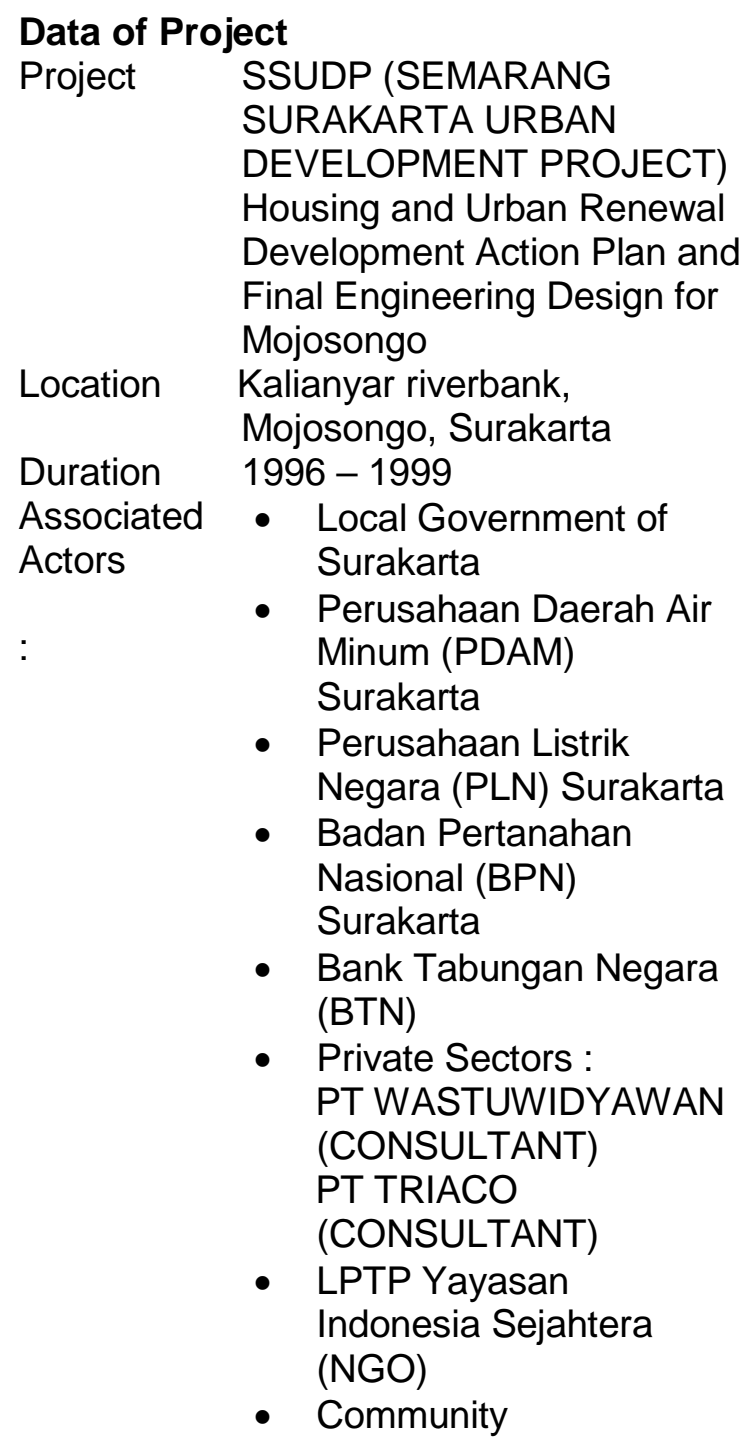

\section{Data of Project}

SURAKARTA URBAN

DEVELOPMENT PROJECT)

Housing and Urban Renewal

Development Action Plan and

Final Engineering Design for

Mojosongo

Mojosongo, Surakarta

$1996-1999$

Associated - Local Government of

- Perusahaan Daerah Air

Minum (PDAM)

Surakarta

Negara (PLN) Surakarta

Badan Pertanahan

Nasional (BPN)

Private Sectors

PT WASTUWIDYAWAN

(CONSULTANT)

PT TRIACO

Payasan

Indonesia Sejahtera

- Community 
Purposes

- To build housing in healthy environment to meet human needs

- To support economic and socio-culture development

- To develop human resources

\section{Problems Occurred}

Based on some observation of the project development process, basically, there were two problems in project application. The first problem was how to build ownership feeling of community to the project. It could be solved by improvement of community participation actively in every step of development programs, planning, designing, developing and implementation. By attending some discussions or meetings, communitybased development also accepted all of community's ideas and needs.

The second one was sustainability, which had closed relationship to funding availability. No financial institutions agreed to fund without collateral and security to get their money back in maturity. The problem was most of the occupants, as poor people, had no key asset could be used as a collateral for borrowing money, except the fact that they have to show their ability to pay it back, too.

Kredit Triguna could be used as the right way out. First, community collected counterpart fund to legalize land status, which would be used as collateral to get loans. After they get the loans in some stages, a part would be used to develop their houses, and the rest could be used to generate income in order to increase their ability to pay.

\section{Result of the Projects}

From Focused Group Discussion (FGD) of the community some results had been approved to be the base of participatory planning programs in housing redevelopment project on RT $01 \mathrm{RW} 03$ Mojosongo area, that are included:

- Physical goals

- Housing redevelopment

- To get proprietary rights of legal and certified land
- To build low cost housing by redevelopment

- Completed social facilities and infrastructures

- To build 'musholla' / praying house for the community because most of them are Moslem, and also meeting hall

- To increase accessibility to purified water supply and telephone lines

- Economic goals

- Income regenerating

- Credit accessibility

- Socio-cultural goals

- Community participation

- Community as subject, not object

Table 2. Detail of Activities in Housing and Urban Renewal for Mojosongo

\begin{tabular}{|c|c|c|}
\hline $\begin{array}{l}\text { PHYSICAL } \\
\text { DEVELOPMENT } \\
\text { PACKAGES }\end{array}$ & $\begin{array}{ll}\text { Redevelopment } \\
\text { - } & 51 \text { houses @ } \\
& 35 \text { m2 } \\
\text { - } & 10 \text { kiosks } \\
\text { - } & \text { social and } \\
& \text { religious } \\
\text { facilities }\end{array}$ & $\begin{array}{l}\text { Purified water } \\
\text { river program/ } \\
\text { Embankment }\end{array}$ \\
\hline $\begin{array}{c}\text { MICRO } \\
\text { PROJECT }\end{array}$ & $\begin{array}{ll}\text { Infrastructure } \\
\text { improvement } \\
\text { - } & \text { road } \\
\text { - } & \text { drainage } \\
\text { - } & \text { purified water } \\
\text { - } & \text { telephone line }\end{array}$ & \\
\hline $\begin{array}{c}\text { ENVIRONMENTAL } \\
\text { MANAGEMENT } \\
\text { ACTIVITY }\end{array}$ & & $\begin{array}{l}\text { Planting trees } \\
\text { at the river } \\
\text { sides }\end{array}$ \\
\hline $\begin{array}{c}\text { SOCIO CULTURAL } \\
\text { ACTIVITY }\end{array}$ & $\begin{array}{l}\text { Preparation and } \\
\text { community } \\
\text { mobilization in } \\
\text { - Community- } \\
\text { based } \\
\text { Association } \\
\text { - Traditional } \\
\text { dancing group } \\
\text { - Al-Qur'an } \\
\text { education for } \\
\text { children }\end{array}$ & \\
\hline $\begin{array}{c}\text { ECONOMIC } \\
\text { GENERATING } \\
\text { ACTIVITY }\end{array}$ & $\begin{array}{l}\text { Capacity building by } \\
\text { - } \quad \text { Lock-brick } \\
\text { housing } \\
\text { building } \\
\text { training } \\
\text { - Training for } \\
\text { making } \\
\text { pavingblock } \\
\text { enterprises }\end{array}$ & \\
\hline
\end{tabular}

Source: Research work 


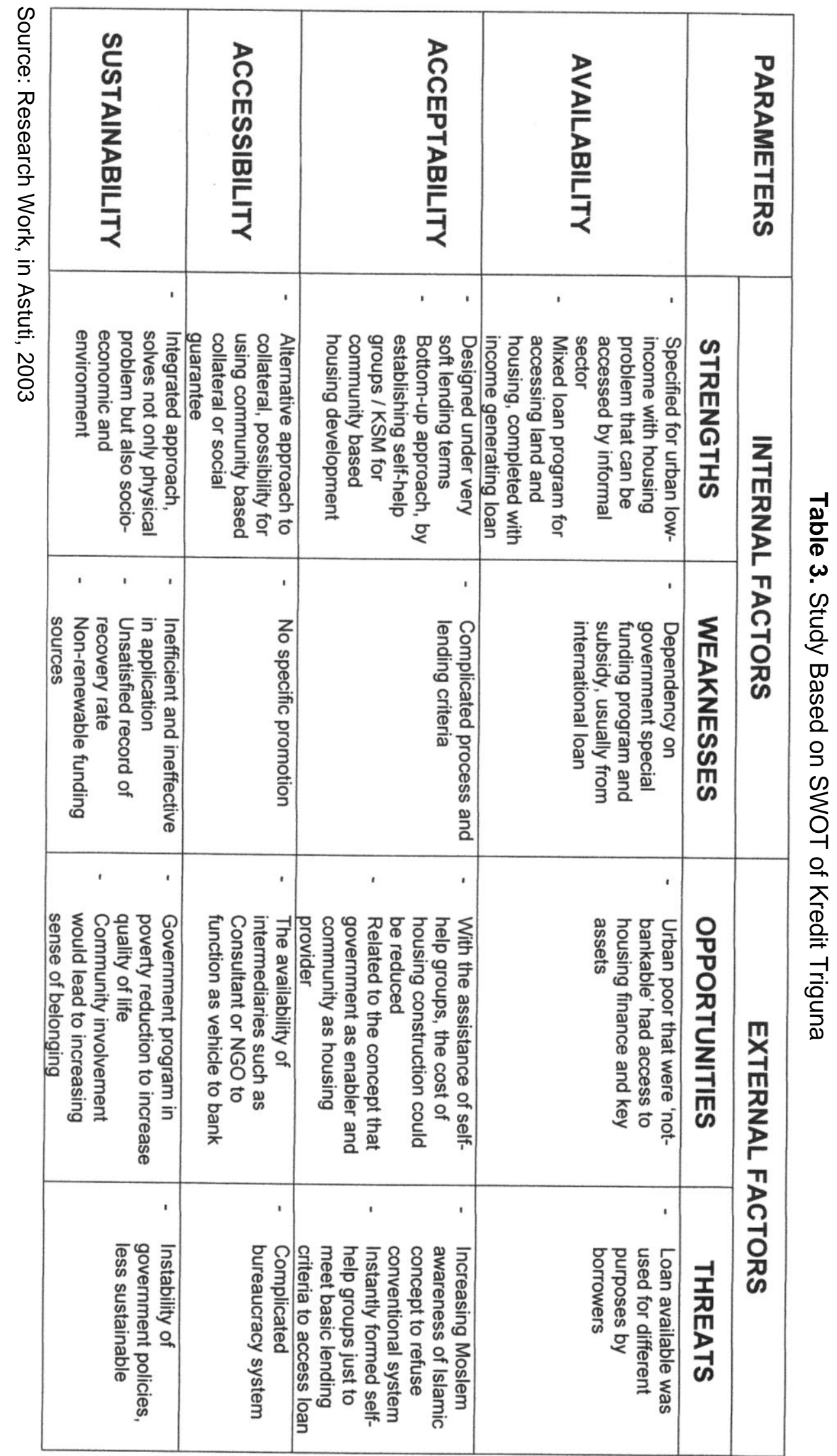


IDENTIFICATION OF REASONS FOR ITS SUCCESS OR FAILURE IN PERFORMANCE

Based on the data of Mojosongo project as the case study, the project has integrated approach between three dimensions, economic, physic and socio-culture.

Diagram 2. The Integrated Approach of Kredit Triguna Implementation on a Housing Project

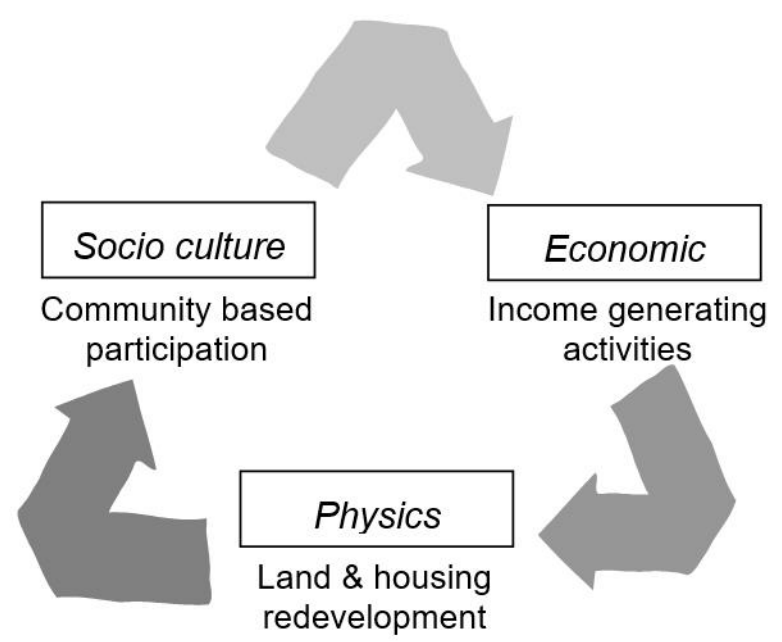

Source : Research Work

The project gives a chance for the poor and low income community to improve participation actively in development process by community-based strategy, to increase prosperity by income generating, and to get access to legal key assets, land and housing, in the same time. It means developing and making efficient use of community capacity. This cycle above describes that starts from community based activities can improve loan accessibility, which is needed for income generating, legalizing land tenure and housing redevelopment.

Based on the nature and the implementation of Kredit Triguna, there are four aspects that have to be included as a standard in an ideal housing-finance implemented. In this research, the four aspects, there are availability, acceptability, accessibility and sustainability, are used as parameters to observe the Kredit Triguna scheme (see table 3).

- Availability: refers to whether supply is available and can meet the need
- Acceptability: refers to whether the scheme is acceptable to the target group

- Accessibility: refers to whether the target group population can use the scheme

- Sustainability: refers to whether the scheme can sustain both from supply and demand sides

\section{CONCLUSION}

As a mixed microcredit policy, Kredit Triguna had an integrated concept that gave access for the low income community and informal sector to financial institution easier. It was rarely found in other scheme, and the low income community needs a kind of innovative lending scheme such as Kredit Triguna.

Therefore, the possible reason why Kredit Triguna stopped lending is mainly measured by the unsatisfied recovery rate. It was caused by mismanagement of sidestreaming risk and also ineffective and inefficient of the scheme in application. Because of the difficulties in monitoring and supervising, the third loan aimed for income generating activities, in fact, was used for other purposes. So, the repayment rate target could not be achieved successfully. Without any satisfied record of repayment, it seems reasonable for the supplier, that was BTN (State Savings Bank) with the assistance of the Indonesian government, to cut off the program.

On the other hand, other reason is the dependency of Kredit Triguna on government policies possibly made the scheme became less sustainable because of the instability of political situation. It had an impact on the availability of institutions involved and also the availability of funding sources. Without the availability of both institutions and funding sources, it would be impossible to continue lending scheme.

And the last, there is another thing that should be considered actually, but it is usually seen as external factor, that is the revival of Moslem awareness movement against conventional financial system based on interest. The impact of the revival trend was not one of the reasons of the discontinuity of Kredit Triguna, but it is potential to grow up to be serious threat in the future. 


\section{REFERENCES}

Negara, Bank Tabungan, 1999. 'Peraturan Direksi dan Surat Edaran Kredit Triguna' (Management Rules and Regulations of Triple Functions Loan), Revised Edition, Bank Tabungan Negara, Jakarta, Indonesia

Panudju, M.Phil., Dr. Ir. Bambang, 1999. 'Pengadaan Perumahan Kota Dengan Peran Serta Masyarakat Berpenghasilan Rendah' (Urban Housing Development by Low-income Community's Participation), Penerbit Alumni, Bandung, Indonesia

Sheng, Yap Kioe, 2000. 'Sustainable Strategies for the Provision of Low-Income Housing in Cities in Developing Countries', CDSI, pages 64-66

Astuti, Dyah Widi, 2003, 'Uncontrolled Housing in Inner-City: Assessing the Possibility of Adopting Triple Functions Loan into Islamic Microfinance System', Institute for Housing and Urban Development Studies, Rotterdam, The Netherlands

www.kimpraswil.go.id 